\title{
COMMUNITY RESPIRATORY SYMPTOMS SURVEY AMONG RESIDENTS IN CLOSE PROXIMITY TO A LANDFILL IN A TROPICAL RURAL AREA
}

\author{
WIDAD FADHULLAH*1,2, NUR FAKHIRA AIDA JAFRI ${ }^{1}$, MOHD HAFIIDZ JAAFAR ${ }^{2}$ AND \\ HASMAH ABDULLAH ${ }^{1}$
}

${ }^{1}$ Environmental and Occupational Health Program, School of Health Sciences, Health Campus, Universiti Sains Malaysia, 16150 Kubang Kerian, Kelantan, Malaysia. ${ }^{2}$ School of Industrial Technology, Universiti Sains Malaysia, 11800 USM Penang, Malaysia.

*Corresponding author: widad@usm.my

Submitted final draft: 29 April 2020

Accepted: 25 June 2020

http://doi.org/10.46754/jssm.2021.04.011

\begin{abstract}
Controlled dumpsite without any liner, leachate treatment and engineered measures can emit landfill gases and hazardous air pollutants to the surrounding environment. This study was conducted to investigate self-reported respiratory symptoms among residents living within $2 \mathrm{~km}$ radius of Beris Lalang Landfill, Bachok, Kelantan. A total of 218 respondents aged between 18 and 65 years old were involved in this crosssectional study from January to March 2019. The questionnaires were adopted from the St George's Respiratory Questionnaire and opted for the symptom score approach. Majority of the respondents were females (64.7 percent), non-smokers (85.3 percent), Malay (94.0 percent) and received tertiary education (43.6 percent). Respondents were reported to have higher proportions of sneezing, runny or blocked noses (35.8 percent) and coughing attack (36.7 percent) compared to the other respiratory symptoms. Associations were reported between respiratory symptoms with gender and exposure to tobacco smoke. Weak significant correlations were found between symptoms score with age of respondents and duration of living in the current home $(\mathrm{p}<0.05)$. This finding implied that proximity to dumpsites did not affect the respiratory symptoms of the communities living within $2 \mathrm{~km}$ radius of the dumpsite. This study provides initial evidence about reported symptoms in populations living near to a landfill as a baseline for future epidemiologic assessments towards sustainable health management.
\end{abstract}

Keywords: Landfill, respiratory symptoms, waste dumpsite, environmental health, sustainable solid waste management.

\section{Introduction}

Sustainable solid waste management requires consideration of social, health, environmental and economic aspects (Al-Khatib et al., 2015). A holistic approach integrating all of these factors should be in place to achieve the sustainable development goals by ensuring access for all to adequate, safe and affordable solid waste collection services, to stop uncontrolled dumping and open burning and to achieve sustainable and environmentally sound management of all wastes by 2030 (Ferronato \& Torreta, 2019). Among these factors, pollution and related health effects have the highest concern of the public on the existence of landfill (Al-Khatib et al., 2015).
Landfill or open dumping are piled with unattended wastes exposed to physical, chemical and biological processes simultaneously accelerating the waste decomposition together with the generation of leachate and landfill gases (Oketola \& Akpotu, 2015). Methane, hydrogen sulphide and ammonia are major air pollutants generated from a landfill which can be exposed to the public via inhalation of airborne emissions, dust or windblown particles from uncontrolled municipal solid waste (MSW) and open dumping (Vrijheid et al., 2002). Emissions of volatile organic compounds mainly, benzene, toluene, ethylbenzene and xylenes (BTEX) from municipal solid waste dumpsites (Klett et al., 2005) may also affect the respiratory system 
via inhalation. These BTEX are associated with serious health implications in particular benzene due to its carcinogenic compounds (USEPA, 2014).

Communities near landfills and open dumps are susceptible to health effects associated with exposure to landfill gases. There have been several epidemiological studies which have investigated whether there is a higher than usual incidence of adverse health events such as cancer, asthma, and eczema in populations living near landfill sites (Mataloni et al., 2016; Rusaik, 2016; Khan et al., 2017; Esphylin et al., 2018). A study conducted by Mataloni et al. (2016) reported that the public who live within 5 $\mathrm{km}$ of a landfill site are exposed to the health risk as they tend to get lung cancer, as well as deaths and hospitalizations for respiratory diseases.

Khan et al. (2016) reported that a higher proportion of households in St. Louis County residents in the Bridgeton Landfill, Missouri, United States area have other respiratory symptoms in the past 12 months than in the comparison area households, including: wheezing (38.5 percent vs. 32.6 percent), gasping for air (13.7 percent vs. 7.6 percent), heaviness in breathing (20.3 percent vs. 14.1 percent), an increased effort to breathe (22.6 percent vs. 12.5 percent), and sore throats (56.6 percent vs. 54.0 percent). Another study was conducted by Rusaik (2016) from households of Blumendhal and Madampitiya sites and PothuwilkumburaKolonnawa sites around the Colombo dumpsite, in Sri Lanka. Identified prominent diseases close to the dumpsite are wheezing (56.3 percent), irritation (57.5 percent), lack of sleep ( 62.2 percent), asthma (73.6 percent), nausea (56.40 percent), burn patches of skin (dark skin) (56.6 percent), dengue (57.6 percent) and viral warts (70.8 percent).

A study by Esphylin et al. (2018) reported the respiratory symptoms in children together with the metals in particulate matter and fingernails of the children residing near landfills in Malacca, Negeri Sembilan, Selangor and Pahang, Malaysia.
In their study, increasing levels of certain metal accumulations in the fingernails were the risk factors that had caused numerous reports of reported respiratory symptoms. Human health risk is also faced by the waste collector workers who are constantly exposed to various types of diseases from sharp objects and unknown waste disposed in bulk by the public (Aminuddin \& Rahman, 2015).

Beris Lalang landfill is the largest active waste dumpsite for the district of Kota Baru in Kelantan, on the East Coast of Malaysia. It receives approximately 350 tonnes of waste daily (Kamaruddin et al., 2016; Fadhullah et al., 2019). Beris Lalang is a typical mukim (sector) of the Telong sub-district of Bachok, Malaysia. This agriculture-based area is situated near the coastline of the South-China Sea in Kelantan, a north-eastern state of Peninsular Malaysia (Huat et al., 2012). The landfill is a peat swamp area surrounded by palm oil plantations and consists of a small stream leading to the Gali River, which eventually flows to Kandis Beachin Bachok (Fadhullah et al., 2019).

Previous studies were conducted to determine the effects of the Beris Lalang Landfill on the environment and health (Huat et al., 2012; Kamaruddin et al., 2016; Khan et al., 2017; Fadhullah et al., 2019). The study by Huat et al. (2012) showed that the rate of helminth infection was 37 percent among children in Beris Lalang, with Trichuris trichiura being the predominantly helminth isolated. One of the independent risk factors for helminth infection was consumption of raw salads and vegetables from the area. The waste was predominantly kitchen and food waste (Periathamby et al., 2009). In 2016, Kamaruddin and his team had revealed the components and proportion of the waste dumped in Beris Lalang landfill and showed that the waste was predominantly organic (33.13 percent), followed by paper (22.01 percent), tetra-paks (12.6 percent), plastic film (8.49 percent) and rigid plastic (8.4 percent). The high amount of organic waste is due to high consumption of dairy products, processed and unprocessed foods (Kamaruddin et al., 2016). 
Khan et al. (2017) reported that few groundwater samples have high concentrations of manganese $(\mathrm{Mn})$, lead $(\mathrm{Pb})$, Iron $(\mathrm{Fe})$ and chromium $(\mathrm{Cr})$ as per World Health Organisation (WHO) standards for potable water. The high concentration of metal ions in groundwater is likely due to untreated effluents from landfill site, municipal wastewater, fertilizers and other activities. Arsenic (As) and lead in groundwater samples collected from the surface of two dug grounds within the vicinity of the Beris Lalang landfill exceeded the standard of Ministry of Health. chromium, $\mathrm{Cu}$ and Lead in leachates exceeded Environmental Quality Act (EQA, 1974)'s standard, whereas $\mathrm{Ni}$, Lead and Zn in surface water of Gali River exceeded the limit of class III National Water Quality Standard (NWQS). These exceedingly high metal concentrations in leachates and its surrounding groundwater and river water relative to their respective standards implies potential leachates migration to the waterbodies within the surrounding vicinity of Beris Lalang dumpsite (Fadhullah et al. 2019). The studies point towards environmental and health risks associated with the existence of the landfill.

In line with this effort, therefore, the main objective of this study is to investigate the respiratory symptoms among residents living within $2 \mathrm{~km}$ radius of Beris Lalang Landfill, Bachok, Kelantan. Specifically, we conducted a cross sectional survey to estimate the frequency of respiratory symptoms among residents, to calculate the score of respiratory symptoms among residents, to determine the association between respiratory symptoms with gender and exposure to tobacco smoke among residents and to predict the relationship between score of symptoms among residents with the age of respondents, duration of living current home and residential distance from landfill. Another existing study reported on health symptoms associated with living near to Sabak landfill (Norsa'adah et al., 2020) but not specifically on respiratory symptoms in Beris Lalang landfill, Kelantan. Our study provides the baseline data for better waste management practices to minimize the risk of air pollution from the landfill to the residents.

\section{Materials and Methods}

\section{Description of Study Area}

A cross-sectional study was conducted among the residents of Kampung Beris Lalang which is located within $2 \mathrm{~km}$ radius to Beris Lalang landfill, Bachok, Kelantan (Figure 1). The distance of $2 \mathrm{~km}$ radius provides the basis for the likely limit of dispersion for landfill emissions (Elliott et al., 2001). The approximate total number of populations in Beris Lalang is 1196 people (PTJB, 2018). The land use of the area is dominated by agriculture $\left(21.54 \mathrm{~km}^{2}, 54.2\right.$ percent) mainly by tobacco plantation (11.81 $\left.\mathrm{km}^{2}\right)$, empty or abandoned land $\left(12.28 \mathrm{~km}^{2}\right.$, 30.9 percent $)$, residential areas $\left(1.56 \mathrm{~km}^{2}, 3.9\right.$ percent), institution and public amenities (1.47 $\mathrm{km}^{2}, 3.7$ percent), waterbodies $\left(1.06 \mathrm{~km}^{2}, 2.69\right.$ percent) and $0.93 \mathrm{~km}^{2}$ of coastal zones as shown in Figure 2 (JPBD, 2018). The meteorological condition of the nearest station in Kota Baru was: average relative humidity (78.1 percent), maximum wind speed was $9.2 \mathrm{~m} / \mathrm{s}$ and the wind direction were within $30^{\circ}$ North/North East to $120^{\circ}$ East/South East during the northeast monsoon (January to March 2019; Malaysian Meteorological Department, 2018).

The landfill has two phases. The first phase began in 2010 by the local state authority and later was taken over by the private waste sector. The second phase started its operation in May 2018 and is contracted to operate until 2030. The current management is actively trying to make this facility a sanitary landfill.

The landfill is a controlled dump with no liner system installed to assess the gas collection and to control Landfill gas (LFG) emissions into to the ambient air. Therefore, this facility has the potential to emit toxic air pollutants due to unavailability of any engineered measures, leachate management and LFG management. 


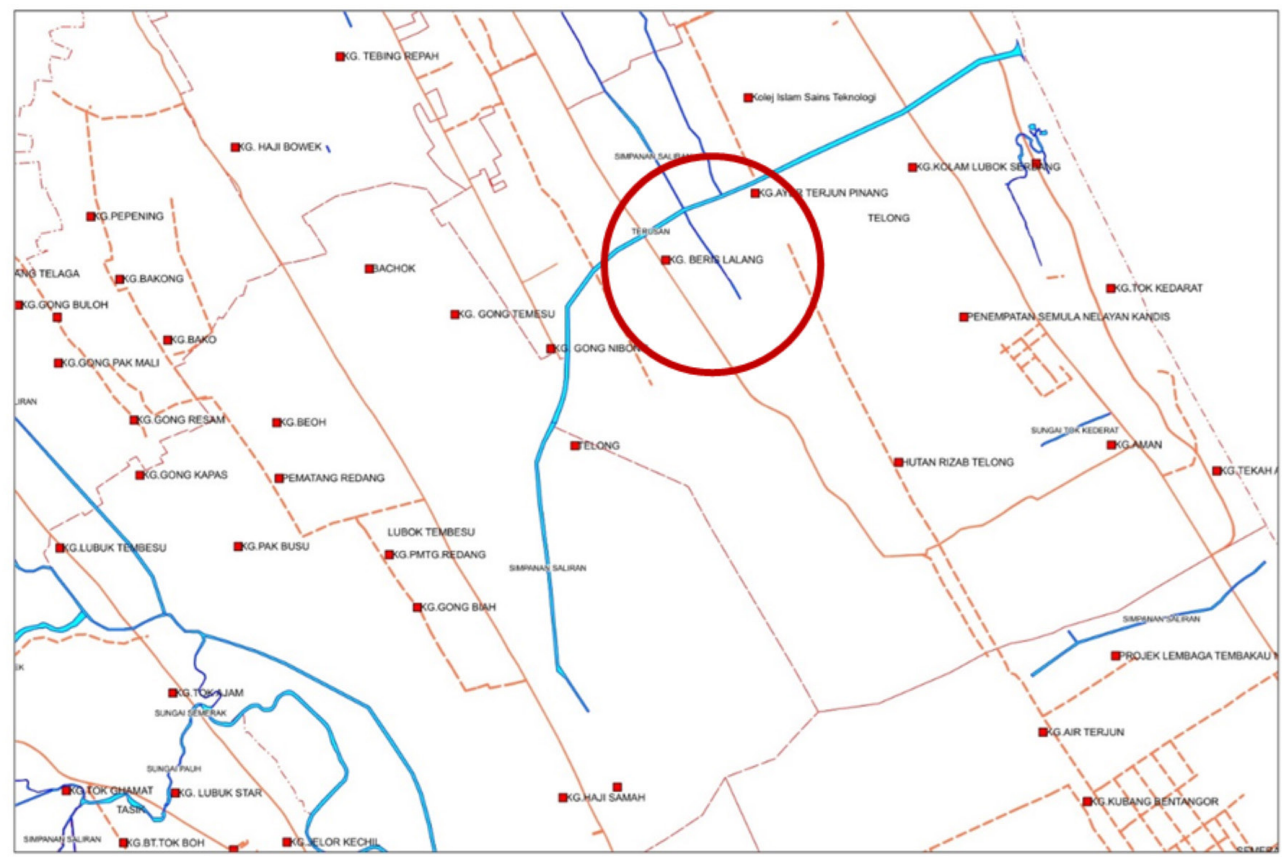

Figure 1: Map of sampling location marked with red circle (JUPEM, 2018)

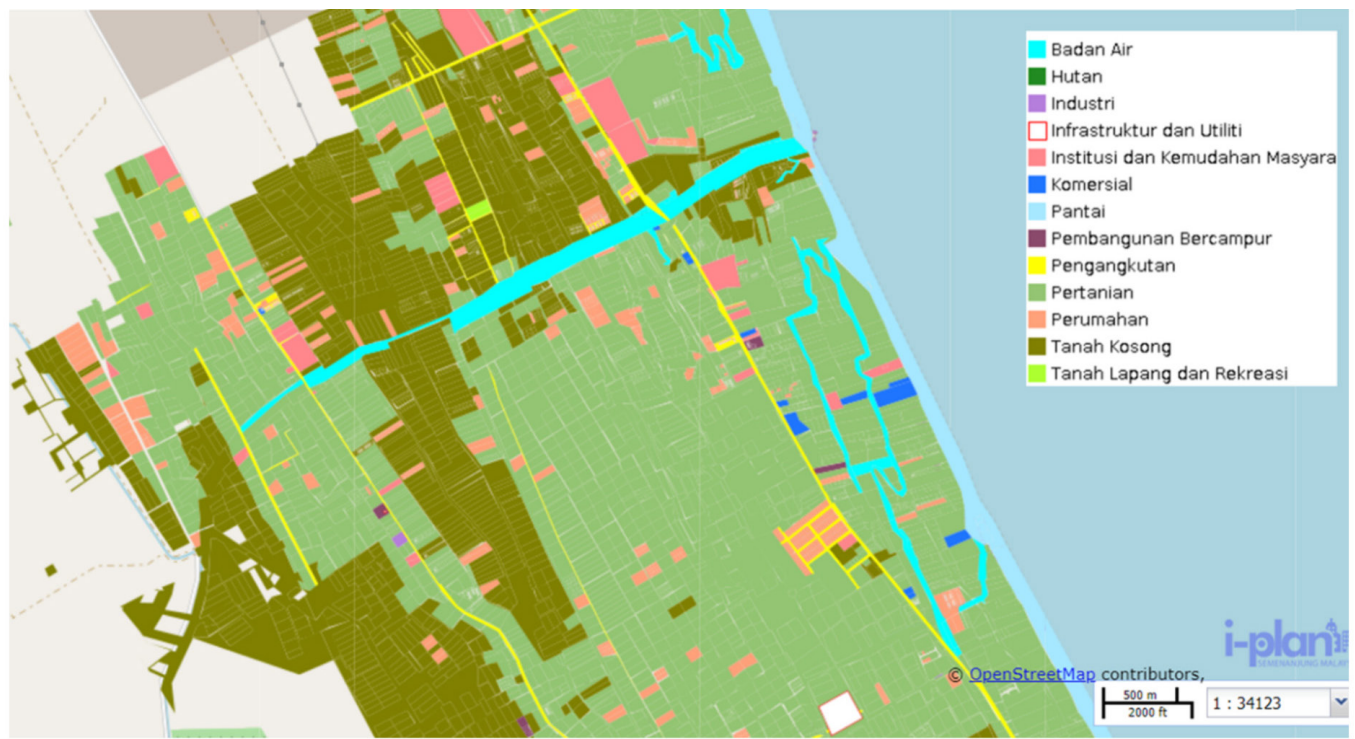

Figure 2: Land use map of Telong sector (mukim) in Bachok, Kelantan (JPBD, 2018)

\section{Data Collection}

\section{Sample and Sampling Population}

Residents aged 18-65 years old living within $2 \mathrm{~km}$ radius from Beris Lalang waste landfill from Kampung Beris Lalang were selected as respondents of this study. The eligibility criteria also included (i) male and female and (ii) respondents who understands Malay Language. A non-probabilistic survey using purposive and convenience sampling was conducted through 
door-to-door survey from January until March 2019. The respondents were recruited by houseto-house visit. The purpose of the study was explained to the respondents and they were invited to participate voluntarily.

The written consents were signed, and the respondents were asked to fill in the questionnaires with guidance of two trained research assistants. Unavailable respondents or respondents who refused to participate were excluded from the survey. Some were not willing to participate because their perspective is that the dumpsite will still be in operation and nothing is done despite answering the questionnaire.

\section{Research Instruments}

This study used the respiratory symptom-based questionnaires because it is a cost-effective tool to enable the identification and baseline assessment of participants with respiratory illnesses (Abbasi et al., 2012). The questionnaire approach was used to identify the incidence or prevalence of respiratory symptoms among respondents. The presence of respiratory symptoms in a person can be early signs that their lungs may react differently, depending on the severity of exposure.

The questionnaire comprises of three parts: Section A consists of socio-demographic information, including age, gender, ethnicity, education level, occupation, smoking habit, length of residence and distance from landfill. Section B was on self-reported respiratory symptoms among respondents within the past 12 months and Section C involved activity and impacts of respiratory problems to their current health. The questionnaire consisted of 37 questions, 78 items and 7 sections comprising of dichotomous (yes and no questions) and a fourpoint Likert scale.

The survey included questions about eight perceived respiratory symptom variables among the households completing the surveys:(1) sneezing, runny or blocked nose (when you did not have cold or a flu); (2) sore throat; (3) cough; (4) chronic cough (for 6 weeks or more);
(5) phlegm from your chest on most days for as much as 3 months each year); (6) wheezing (and whistling when you did not have any cold); (7) shortness of breath (woken up by an attack at any time) and (8) chest tightness (woken up by an attack at any time).

The questionnaire was adopted from St. George's Respiratory Questionnaire (SGRQ) to assess the respondent's perception of their recent respiratory problems (Jones, 2009). SGRQ has been used in a range of disease groups including asthma, chronic obstructive pulmonary disease and bronchiectasis, and in randomised controlled therapy trials and population surveys (Jones, 2009).

From the questionnaire, the symptoms score were determined from the effect of respiratory symptoms, their frequency and severity. The symptoms include frequency of cough, wheezing, breathlessness and duration, and frequency of breathlessness or wheezing. The activity components are concerned with routines or any conditions that cause or are limited by breathlessness.

Impacts cover aspects concerning social functioning and psychological disturbances resulting from chest trouble and breathing. The scoring for the symptom score ranged from $0-100$, where a higher number indicates poorer health (Gelpi et al., 2016). The symptom score was calculated using the SGRQ apps from the Viro-immunology Research Unit, Department of Infectious Diseases, Copenhagen University Hospital (Gelpi et al., 2016). The score was derived by dividing the summed weights (of all questions related to respiratory symptoms, activity, and impacts) by the maximum possible weight using an Excel calculator (Jones, 2009). The step-by-step calculation was outlined in the St George's Respiratory Questionnaire Manual (Jones \& Ford, 2009).

The survey was initially made in English and then translated into Malay for better public participation. The translation was checked and validated by experts in language and translation. A pilot test was conducted to around 30 persons from representative samples of the households 
(number of subjects) and 10-15 minutes were taken by the respondents to answer the given questionnaire. The pilot test was conducted to determine the suitability of the terms, the arrangement of items and arrangement of choices for each item as well as the time taken by respondents to complete the questionnaires.

The reliability Cronbach's alpha test of this questionnaire was found to be acceptable $(\alpha=0.80)$. Ethical approval for this study was obtained from the Ethic Committee of Universiti Sains Malaysia (USM/JEPeM/18110638).

\section{Data Analysis}

All the data were analysed using Statistical Package for Social Science (SPSS) software, version 24.0 for windows. Normality test was checked using skewness, kurtosis and Kolmogorov-Smirnov test and it was found that these data were not normally distributed, hence non-parametric tests were used. Descriptive statistics were used to analyse the socio-demographic information, respiratory symptoms, and symptoms score.

To measure differences in the means of continuous variables such as respondent's age, duration of living in current home and residential distance from the landfill, the Mann-Whitney and Kruskall-Wallis tests were used. Inferential data analysis was conducted using Pearson's Chi Square test to measure the association between respiratory symptoms with demographic and smoking factors which fell under categorical data.

Spearman's rank correlation was used to predict the relationship between score of symptoms among residents that live within $2 \mathrm{~km}$ from Beris Lalang landfill with age of respondents, duration of living in current home and residential distance from landfill.

\section{Results and Discussion}

\section{Socio-demographic Background}

Majority of the respondents who lived within $2 \mathrm{~km}$ radius from the dumpsite were female $(\mathrm{N}=141,64.7$ percent) and belonged to the
Malay ethnicity group ( $\mathrm{N}=205,94$ percent) as shown in Table 1. Majority of the respondents who participated in this survey $(\mathrm{N}=218)$ were Malay (94 percent) as many of the villagers are Muslim Malay (Huat et al., 2012) and the major ethnicity in Kelantan are Malays (Department of Statistics, 2010).

The questionnaires were distributed, and the sessions were done during daytime where we believed that during that time, the males were at work and were not at home; therefore, the feedback was mostly from female respondents (64.7 percent). The highest education received by respondents are tertiary level $(\mathrm{N}=95,43.6$ percent), which could be hypothesise that these respondents are educated enough to understand and know the area very well to take precautions to avoid any health issues primarily related to air pollution.

Education is critical to social and economic development and has a profound impact on population health (Zimmerman \& Woolf, 2014). Environmental education has shown that people of all ages have positive attitudes and are aware of air pollution issues associated with population increase, industrialization and consumption patterns (Teksoz, 2011). The majority of the respondents were also employed $(\mathrm{N}=73,33.5$ percent $)$ and full-time house person $(\mathrm{N}=53,24.3$ percent).

Most of the respondents were also nonsmokers ( $\mathrm{N}=186,85.3$ percent) and were not regularly exposed to tobacco smokes $(\mathrm{N}=126$, 57.8 percent). This low prevalence could be influenced by the gender distribution of the respondents who were mainly females.

Females are generally non-smokers due to traditional norms and perception that smoking is a male dominant habit among Asians (Parkinson et al., 2009). Out of the 218 respondents, most of them did not have any respiratory condition $(\mathrm{N}=156,71.6$ percent) whereas 12.8 percent reported to have asthma $(\mathrm{N}=28)$ within the last 12 months. There were also respondents who did not know their respiratory condition which is related to the question about emphysema $(\mathrm{N}=34,15.6$ percent $)$. 
Table 1: The sociodemographic background of the respondents $(\mathrm{N}=218)$

\begin{tabular}{|c|c|c|}
\hline Variables & Category & $\mathbf{N}(\%)$ \\
\hline Age (year) & Mean \pm standard deviation & $39.79 \pm 0.89$ \\
\hline Duration of living in the current home (year) & Mean \pm standard deviation & $8.05 \pm 0.14$ \\
\hline Residential distance from landfill (km) & Mean \pm standard deviation & $1.15 \pm 0.023$ \\
\hline \multirow[t]{2}{*}{ Gender } & Male & $77(35.3)$ \\
\hline & Female & $141(64.7)$ \\
\hline \multirow[t]{4}{*}{ Ethnicity } & Malay & $205(94.0)$ \\
\hline & Chinese & $9(4.1)$ \\
\hline & Indian & $4(1.8)$ \\
\hline & Other & 0 \\
\hline \multirow[t]{4}{*}{ Level of education } & None & 0 \\
\hline & Primary & $43(19.7)$ \\
\hline & Secondary & $80(36.7)$ \\
\hline & Tertiary & $95(43.6)$ \\
\hline \multirow[t]{4}{*}{ Smoking habit } & No & $186(85.3)$ \\
\hline & Sometimes & $5(2.3)$ \\
\hline & Yes & $27(12.4)$ \\
\hline & Ex-smoker & 0 \\
\hline \multirow[t]{3}{*}{ Regularly exposed to tobacco smoke } & No & $126(57.8)$ \\
\hline & Yes & $92(42.2)$ \\
\hline & Do not know & 0 \\
\hline \multirow[t]{3}{*}{ Respiratory condition } & No & $156(71.6)$ \\
\hline & Yes & $28(12.8)$ \\
\hline & Do not know & $34(15.6)$ \\
\hline \multirow[t]{8}{*}{ Occupation } & Employed & $73(33.5)$ \\
\hline & Self-employed & $43(19.7)$ \\
\hline & Unemployed & $18(8.3)$ \\
\hline & Not working because of poor health & $2(0.9)$ \\
\hline & Full-time house-person & $53(24.3)$ \\
\hline & Student & $17(7.8)$ \\
\hline & Retired & $12(5.5)$ \\
\hline & Other & 0 \\
\hline
\end{tabular}

\section{Respiratory Symptoms}

A higher percentage of respondents' experience cough $(\mathrm{N}=80,36.7$ percent $)$ and sneezing, runny or blocked nose ( $\mathrm{N}=78,35.8$ percent) compared to the other respiratory symptoms in the past 12 months (Table 2). Coughing is a symptom of both respiratory and non-respiratory origin which functions to clear the lung airways of fluids, mucus or foreign materials including dust or particulate matter apart from being a physiological barrier against irritant substances that reach the respiratory tract (Singh \& Singh, 2013). 
Coughs can be categorized as acute (less than three weeks) or chronic (greater than three weeks) (Sharma et al., 2019). In this study, only 36.7 percent $(\mathrm{N}=80)$ of respondents' experience acute cough while another 8.3 percent $(\mathrm{N}=18)$ experience chronic cough. Hence, it is important for individuals to be aware of prolonged coughing attack which may persists more than 3 weeks' time. An individual's lifestyle, quality-of-life and sense of well-being can be significantly affected by the presence of cough (Iyer \& Joshi, 2013).

Nevertheless, in this study, overall, respondents who do not have respiratory symptoms (wheezing, wheezing when did not have cold, chest tightness, cough, chronic cough, phlegm, breathing trouble, shortness of breath, sore throats and sneezing, runny or blocked noses) are higher than the ones having respiratory symptoms (Table 2). Majority of the respondents also reported that their current health is in very good $(\mathrm{N}=66,30.3$ percent $)$ and good conditions ( $\mathrm{N}=70,32.1$ percent).

Overall, this self-reported respiratory symptom survey pointed out that the respiratory health of the respondents was in good condition. According to Voll-Aanerud et al. (2008), the burden of respiratory symptoms is more strongly associated with generic health related quality of life than is lung function in the general population sample.

The determinants of health include the social and economic environment, the physical environment, the person's characteristics, and behaviours and many others including income and social status, education, social support networks, genetic, health services, and gender (World Health Organization, 2019).

Table 2: Distribution of respiratory symptoms among respondents [N (\%)]

\begin{tabular}{lc}
\hline Variable & N (\%) \\
\hline Wheezing & $156(71.6)$ \\
No & $62(28.4)$ \\
Yes & \\
Wheezing when did not have cold & $161(73.9)$ \\
No & $57(26.1)$ \\
Yes & \\
Chest tightness & $179(82.1)$ \\
No & $39(17.9)$ \\
Yes & \\
Cough & $138(63.3)$ \\
No & $80(36.7)$ \\
Yes & \\
Chronic cough & $200(91.7)$ \\
No & $18(8.3)$ \\
Yes & \\
Phlegm & $203(93.1)$ \\
No & $15(6.9)$ \\
Yes &
\end{tabular}




\begin{tabular}{lc}
\hline Breathing trouble & $189(86.7)$ \\
No & $29(13.3)$ \\
Yes & \\
Shortness of breath & $179(82.1)$ \\
No & $39(17.9)$ \\
Yes & \\
Sore throat & $184(84.4)$ \\
No & $34(15.6)$ \\
Yes & \\
Sneezing, runny or blocked nose & $140(64.2)$ \\
No & $78(35.8)$ \\
Yes & \\
How respondents rated their current health? & $66(30.3)$ \\
Very good & $70(32.1)$ \\
Good & $49(22.5)$ \\
Fair & $18(8.3)$ \\
Poor & $15(6.9)$ \\
\hline
\end{tabular}

Association between Respiratory Symptoms with Gender and Exposure to Tobacco Smokers

Significant associations were found between respiratory symptoms with gender and exposure to tobacco smoke (Table 3 and 4). Females are more vulnerable to experience breathing conditions compared to males. This factor could be related to the difference in the physiology of the nose between men and women; men are characterised by larger nasal cavities, and longer, narrower and higher nasal floors than females of the same body size (LoMauro \& Aliverti, 2018). García-Martínez et al. (2016) suggest that difference dimorphism in the human skull of male and female influences the morphology of the upper airways.

The respiratory symptoms were significantly different among those who were directly exposed to tobacco smoke (Table 4). The current findings showed that wheezing followed by sneezing, runny, or blocked nose and cough symptoms are higher proportion compared to other symptoms. Passive smoking or environmental tobacco smoke is strongly related to respiratory symptoms including wheezing, chronic coughing and phlegm production (Larsson et al., 2003). The frequent exposure to the landfill airborne irritants like hydrogen sulphide may eventually irritate the nose and lung of the individual.

Highly water-soluble and reactive irritants (such as chlorine, ammonia, sulphur dioxide, and formaldehyde) readily dissolve in mucous membrane water and quickly interact with the nose's sensory structures called rhinitis (Shusterman, 2011). Rhinitis or inflammation of the nasal membranes is characterized by sneezing, nasal congestion, nasal itching, and rhinorrhoea (Sheikh, 2018).

Our results showed that respondents who were not exposed to tobacco smoke experienced less respiratory symptoms; wheezing $(\mathrm{N}=8$, 3.7 percent, $)$ shortness of breath $(\mathrm{N}=4,1.8$ percent), chest tightness ( $\mathrm{N}=8,3.7$ percent) and squeezing, runny or blocked noses $(\mathrm{N}=25,11.5$ percent). Thus, this finding implies that people 
who smoke and are regularly exposed to tobacco smoke may develop respiratory symptoms, because of the tobacco smoke itself. Smoking status was directly related to the presence of respiratory symptoms (Amela et al., 2012).

Table 3: Results of the chi-square test for associations between the dependent variable 'reported respiratory symptoms' with gender

\begin{tabular}{|c|c|c|c|c|}
\hline \multirow{2}{*}{ Variable } & \multicolumn{2}{|c|}{ Gender, N (\%) } & \multirow[t]{2}{*}{$X^{2}(d f)$} & \multirow[t]{2}{*}{$P$ value } \\
\hline & Male & Female & & \\
\hline Sore throat & & & $18.456(1)$ & 0.001 \\
\hline Yes & $24(11.0 \%)$ & $12(5.5 \%)$ & & \\
\hline No & $53(24.3 \%)$ & $129(59.2 \%)$ & & \\
\hline Chronic cough & & & $9.982(1)$ & 0.002 \\
\hline Yes & $13(6.0 \%)$ & $6(2.8 \%)$ & & \\
\hline No & $64(29.4 \%)$ & $135(61.9 \%)$ & & \\
\hline Phlegm & & & $10.188(1)$ & 0.001 \\
\hline Yes & $11(5.0 \%)$ & $4(1.8 \%)$ & & \\
\hline No & $66(30.3 \%)$ & $137(62.8 \%)$ & & \\
\hline Wheezing & & & $10.066(1)$ & 0.002 \\
\hline Yes & $32(14.7 \%)$ & $30(13.8 \%)$ & & \\
\hline No & $45(20.6 \%)$ & $111(50.9 \%)$ & & \\
\hline Shortness of breath & & & $5.474(1)$ & 0.019 \\
\hline Yes & $18(8.3 \%)$ & $16(7.3 \%)$ & & \\
\hline No & $59(29.4 \%)$ & $125(57.3 \%)$ & & \\
\hline Wheezing without cold & & & $8.175(1)$ & 0.006 \\
\hline Yes & $29(13.3 \%)$ & $28(12.8 \%)$ & & \\
\hline No & $48(22.0 \%)$ & $113(51.8 \%)$ & & \\
\hline
\end{tabular}

Note: Only significant associations are shown in the table.

Symptoms Score, Age, Duration and Distance

Exposure to outdoor and indoor environmental contaminants can cause a variety of respiratory symptoms, such as breathing problems (AlDelaimy et al., 2014). The proximity to the landfill site is identified as the indicator of exposure and determined by measuring the distance from the households to the landfill (Mataloni et al., 2016). Apart from the distance from the landfill, duration of living at the current home are identified as significant factors affecting the respiratory symptoms (Rusaik, 2016). Out of 218 respondents, the symptoms score ranged from 2.12 to 99.20 (Table 5). Symptom score of more than 90 were associated with older respondents aged between 50 and 65 years old and among the middleaged respondents between 35 and 49 years old compared to the younger respondents.

Among the respondents, the majority were people who were nearly 40 years old. This group is considered to be middle-aged adults (Petry, 2002). The respiratory system changes with age, declining in function in a similar manner as other organs. Age-related changes in the lungs include decreases in measures of lung function, 
Table 4: Results of the chi-square test for associations between the dependent variable 'reported respiratory symptoms' with exposure to tobacco smokes

\begin{tabular}{|c|c|c|c|c|}
\hline \multirow{2}{*}{ Variable } & \multicolumn{2}{|c|}{ Exposure to tobacco smokes, $N(\%)$} & \multirow[b]{2}{*}{$X^{2}(d f)$} & \multirow[b]{2}{*}{$P$ value } \\
\hline & Yes & No & & \\
\hline Sore throat & & & $59.057(1)$ & 0.001 \\
\hline Yes & $36(16.5 \%)$ & $0(0.0 \%)$ & & \\
\hline No & $56(25.7 \%)$ & $126(57.8 \%)$ & & \\
\hline Chronic cough & & & $28.506(1)$ & 0.001 \\
\hline Yes & $19(8.7 \%)$ & $0(0.0 \%)$ & & \\
\hline No & $73(33.5 \%)$ & $126(57.8 \%)$ & & \\
\hline Phlegm & & & $22.061(1)$ & 0.001 \\
\hline Yes & $15(6.9 \%)$ & $0(0.0 \%)$ & & \\
\hline No & $77(35.3 \%)$ & $126(57.8 \%)$ & & \\
\hline Wheezing & & & $71.593(1)$ & 0.001 \\
\hline Yes & $54(24.8 \%)$ & $8(3.7 \%)$ & & \\
\hline No & $38(17.4 \%)$ & $118(54.1 \%)$ & & \\
\hline Shortness of breath & & & $34.996(1)$ & 0.001 \\
\hline Yes & $30(13.8 \%)$ & $4(1.8 \%)$ & & \\
\hline No & $62(28.4 \%)$ & $122(56.0 \%)$ & & \\
\hline Chest tightness & & & $27.071(1)$ & 0.001 \\
\hline Yes & $31(14.2 \%)$ & $8(3.7 \%)$ & & \\
\hline No & $61(28.0 \%)$ & $118(54.1 \%)$ & & \\
\hline $\begin{array}{l}\text { Squeezing, runny or } \\
\text { blocked nose }\end{array}$ & & & $24.486(1)$ & 0.001 \\
\hline Yes & $49(22.5 \%)$ & $25(11.5 \%)$ & & \\
\hline No & $43(19.7 \%)$ & $101(46.3 \%)$ & & \\
\hline
\end{tabular}

Note: Only significant associations are shown in the table.

decreases in peak inflow and gas exchange, weakening of the respiratory muscles and a decline in the effectiveness of lung defence mechanisms (Lechtzin, 2017). According to Kalhan et al. (2018), the persistent respiratory system in adults is associated with an accelerated decline in lung function, incident obstructive and restrictive physiology, and a higher probability of future radiographic emphysema.

There is a significant relationship between age and symptoms score $(\mathrm{R}=0.185, \mathrm{p}=0.006)$ as shown in Table 6. This significant positive relationship indicates that the older the respondents, the higher the symptom score. Although the relationship is significant, but the $\mathrm{R}$ value is weak; hence this study implies that age does not largely impact the symptoms score.

Similarly, weak significant relationships were found between duration of residence at current home with the symptom scores suggesting no relations between these two factors. Most of the respondents have lived at their residence for about nine years which is within the range of the existence of the landfill which started in 2010. 
The landfill facility was in operation for the past nine years, replacing the previous landfill in Telok Kitang, which has ceased operation. More recently buried waste (less than ten years) produces more landfill gas through bacterial decomposition, volatilization, and chemical reactions than do older waste (Agency for Toxic Substances and Disease Registry, 2001). According to Rawat \& Ramanathan (2011), the rate and volume of landfill gas produced at a specific site depends on the characteristics of the waste (e.g., composition and age of the refuse) and a number of environmental factors (e.g., the presence of oxygen in the landfill, moisture content, and temperature).

However, due to no high significant correlation between the symptoms score and duration of living at current home among respondents $(\mathrm{R}=0.165, \mathrm{p}=0.015)$, therefore we hypothesise that the landfill did not reach the 'severity stage' after nine years of operation.

The residential distance from landfill and symptom score were not significant (Table 6), suggesting that distance was not the prominent factor for the community to develop the respiratory symptoms. The non-significant and weak relationship is due to multiple possible confounding risk factors related to developing respiratory symptoms in individual including diet and nutrition, indoor air pollution, passive smoking, early life risk factors, outdoor air pollution, tobacco smoking, genetic susceptibility and occupational risk factors (European Lung Foundation, 2019).

Besides, environmental factors such as meteorological condition may also affect the dispersion of the LFG and airborne pollutants and particles from the landfill to the community. Landfill sites may be a source of airborne toxic chemical contamination by evaporation or via windblown particles (Vrijheid et al., 2002).

Atmospheric dispersion can travel from a landfill site depending on the wind direction and weather patterns at that specific time (Okeke \&Armour 2000). The wind direction from the nearest station in Kota Baru, $20 \mathrm{~km}$ radius from the study area was from $30^{\circ} \mathrm{N} / \mathrm{NE}$ to $120^{\circ} \mathrm{E} / \mathrm{SE}$ during the northeast monsoon (January to March 2019). Hypothetically, this wind direction might plausibly direct the wind away from $\mathrm{Kg}$ Beris Lalang, hence the trivial relationship.

\section{Conclusion}

In conclusion, our study found out that a higher percentage of respondents' experience cough $(\mathrm{N}=80,36.7 \%)$ and sneezing, runny or blocked nose $(\mathrm{N}=78,35.8$ percent $)$ compared to the other respiratory symptoms in the past 12 months among residents living within $2 \mathrm{~km}$ radius of Beris Lalang Landfill, Bachok, Kelantan.

Significant associations were found between respiratory symptoms with gender and exposure to tobacco smoke $(p<0.001)$. These associations imply that firstly, females are more vulnerable to experience breathing conditions compared to males and secondly, respondents who smoke and are regularly exposed to tobacco smoke may develop respiratory symptoms because of the tobacco smoke itself.

Many confounding factors affect the health of individuals and communities which can be determined by their circumstances and environment.

There is weak significant relationship between age and symptoms score $(\mathrm{R}=0.185$, $\mathrm{p}=0.006$ ) and between duration of residence at current home with the symptom scores $\mathrm{R}=0.165$, $p=0.015$ ), suggesting no relations between these two factors. Similarly, the relationships between the residential distance from landfill and symptom score were not significant $(\mathrm{R}=0.028$, $\mathrm{p}=0.635$ ), suggesting that distance was not a prominent factor for the community to develop the respiratory symptoms.

Apart from the many confounding factors, there are several limitations of this study. Firstly, a cross-sectional study could not ascertain the cause-effect relationship because it simply measures association between dumpsite exposure and the respiratory effects. The study could not verify that the sources of toxicants and 
LFG dispersion in the air caused the respiratory symptoms among respondents who live in $2 \mathrm{~km}$ radius from Beris Lalang Landfill.

Secondly, the main approach of our study depends on self-reported symptoms, which may be subject to bias. Thirdly, the trivial relationship between symptom score and age, duration and distance from the landfill could be improvised by incorporating comparisons with more municipal landfills and control areas.

Despite not showing any conclusive determinants of respiratory symptom, this study does provide initial evidence about reported symptoms in this population to support more substantial and more complex epidemiologic designs as a baseline for community health, management and sustainability.

Further study is required to investigate which toxicants residents are being exposed to and the source of that exposure considering meteorological conditions in the area. The finding from this study calls for a more focused and sustained public awareness programs in relation to respiratory health among rural residents. Such studies will be able to document the source of toxicants and how air toxicants may lead to exposure of grossly underserved populations and potential plans to prevent future exposure through planning remediation effort among municipalities, district health officers, and nearby residents.

\section{Acknowledgements}

Author(s) extend their gratitude to everybody who completed the questionnaires. This research has been funded by the Ministry of Higher Education Malaysia (Postdoctoral Fellowship SLAB) and Universiti Sains Malaysia. This research is part of a dissertation which was submitted as partial fulfilment to meet requirements for the degree of Environmental and Occupational Health at Universiti Sains Malaysia Health Campus.

\section{References}

Abbasi, I. N., Ahsan, A., \& Nafees, A. A. (2012). Correlation of respiratory symptoms and spirometric lung patterns in a rural community setting, Sindh, Pakistan: A cross sectional survey. $B M C$ Pulmonary Medicine, 12, 81. https://doi. org/10.1186/1471-2466-12-81

Agency for Toxic Substances and Disease Registry. (2019, May 1). Landfill Gas Primer - An Overview for Environmental Health Professionals. https://www.atsdr. cdc.gov/HAC/landfill/html/intro.html.

Al-Delaimy, W. K., Larsen, C. W., \& Pezzoli, K. (2014). Differences in health symptoms among residents living near illegal dump sites in Los Laureles Canyon, Tijuana, Mexico: A cross sectional survey. International Journal of Environmental Research and Public Health, 11(9), 95329552. doi:10.3390/ijerph110909532.

Al-Khatib, I. A., Abu Hammad, A., Sharkas, O. A., \& Sato, C. (2015). Public concerns about and perceptions of solid waste dump sites and selection of sanitary landfill sites in the West Bank, Palestinian territory. Environ. Monit. Assess., 187, 186, 1-15.

Amela, D., Esad, P., Alen, D., Hasanbegovic, I., Mušanovic, J., \& Spasojevic, N. (2012). 'The impact of respiratory symptoms presence on quality of life of tobacco smokers, Arch Pharma Pract, Official Publication of Archives of Global Professionals, Saudi Arabia, 3(4), 274-282.

Aminuddin, M. S., \& Rahman, H. A. (2015). Health risk survey for domestic waste management agency workers: Case study on Kota Bharu Municipal Council (MPKB), Kelantan, Malaysia. International Journal of Environmental Science and Development, 6(8), 629-634.

Department of Statistics Malaysia (2010). (2019, Oct 10). Kelantan. https://www. citypopulation.de/php/malaysia-admin. php?admlid=03. 
Elliot, P., Briggs, D., Morris, S., Hoogh, C. D., Hurt, C., Jensen, T. K., Maitland, I., Richardson, S., Wakefield, J., \& Jarup, L. (2001). Risk of adverse birth outcomes in populations living near landfill sites, $B M J$, 323(7309), 363-368.

Environment Quality Act. (1974). (2018, April 6). Akta Kualiti Alam Sekeliling. https:// www.doe.gov.my/portalv1/en/tentangjas/perundangan/akta-kaedah-peraturanarahan-2/akta.

Esphyllin, D., Ismail, S. N. S., Praveena, S. M., Hashim, Z., \& Abidin, E. Z. (2018). The association of reported respiratory symptoms among children in Malaysia with particulate matter exposure in municipal solid waste landfills. Malaysian Journal of Medicine and Health Sciences, 14(SP1), 2-11. (eISSN 2636-9346).

European Lung Foundation. (2019). (March 3, 2019). Risk Factors. https://www. europeanlung.org/en/lung-disease-andinformation/risk-factors/.

Ferronato, N., \& Torretta, V. (2019). Waste mismanagement in developing countries: A review of global issues. International Journal of Environmental Research and Public Health, 16(6), 1060, 23-28. https:// doi.org/10.3390/ijerph16061060.

Fadhullah, W., Kamaruddin, M. A., Ismail1, N., Sansuddin N., \& Abdullah, H. (2019) Characterization of landfill leachates and its impact to groundwater and river water quality: A case study in Beris Lalang Waste Dumpsite, Kelantan. Pertanika Journal Science \& Technology, 27(2), 633 - 646.

García-Martínez, D., Torres-Tamayo, N., Torres-Sanchez, I., García-Río, F., \& Bastir, M. (2016). Morphological and functional implications of sexual dimorphism in the human skeletal thorax. American Journal of Physical Anthropology, 161(3), 467-477.

Gelpi, M., Argentiero, J., Jones, P. W., \& Ronit, A. (2016). A scoring application for the St. George's respiratory questionnaire. CHEST, 150(3), 747-748.
Huat, L. B., Mitra, A. K., Jamil, N. I., Dam, P. C., Mohamed, H. J., \& Muda, W. A. (2012). Prevalence and risk factors of intestinal helminth infection among rural Malay children. Journal of Global Infectious Diseases, 4(1), 10-14. doi:10.4103/0974777X.93753.

Ishii, Y. (2013). Smoking and respiratory diseases. Nihon Rinsho. Japanese Journal of Clinical Medicine, 71(3), 416-420.

Iyer, R. K., \& Joshi, J. M. (2013). Future drugs for the treatment of dry cough. The Journal of the Association of Physicians of India, 61(5 Suppl), 14-16.

Malaysian Metereological Department. (2018). (2019, October 10). http://www.met.gov. $\mathrm{my} /$ projection/rain/48615.

Jones, P. W., Harding, G., Berry, P., Wiklund, Chen W-H., \& Kline Leidy, N. (2009). Development and first validation of the COPD Assessment Test. Eur Respir J, 34(3), 648-654. https://doi. org/10.1183/09031936.00102509.

Jones, P. W., \& Forde, Y. (2009). (May 1, 2019). St George's Respiratory Questionnaire Manual. London, University of London. www.healthstatus.sgul.ac.uk/sgrq/sgrqdownloads.

JPBD. (2018). (October 10, 2019). I-Plan Malaysia. https://iplan.townplan.gov.my/.

Kalhan, R., Dransfield, L. A., Colangelo, L. A., Cuttica, M. J., Jacobs, D. R., Thyagarajan, B., Estepar, R. S. J., Harmouche, R., Onieva, J. O., Ash, S. Y., Okajima, Y., Iribarren, C., Sidney, S., Lewis, C. E., Mannino, D. M., Liu, K., Smith, L. J., \& Washko, G. R. (2018). Respiratory symptoms in young adults and future lung disease. The CARDIA lung study. American Journal of Respiratory and Critical Care Medicine, 197(12), 1616-1624.

Kamaruddin, M. A., Yusoff, M. S., Aziz, H. A., Adlan, M. N., Zaman, N. Q., \& Mahmood, N. Z. (2016). Assessment of municipal solid waste generation, composition and 
recyclable potential at selected Kelantan dumping sites, Malaysia. Journal of Scientific Research and Development, 3(5), 204-211.

Khan, M. M. A., Mansor, H. E., Aflatoon, N. H., \& Kishan Raj Pillai, M. (2017). Distribution of trace elements in groundwater around Beris Lalang landfill Bachok, Kelantan, Malaysia. Asian Journal of Water, Environment and Pollution, 14(1), 41-50.

Klett, N., Edil, T. B., Benson, C. H., \& Connelly, J. (2005). Evaluation of volatile orrganic compounds in Wisconsin Landfill Leachate and Lysimeter Samples, University of Wisconsin, Water Resources Institute.

Larsson, M. L., Loit, H. M., Meren, M., Põlluste, Magnusson, A., Larsson, K., \& Lundbäck, K. (2003). Passive smoking and respiratory symptoms in the FinEsS study. European Respiratory Journal, 21(4), 672-676.

Lechtzin, N. (2017). (2019, January 13). Effects of Aging on the Respiratory System - Lung and Airway Disorders. https:// www.msdmanuals.com/home/lung-andairway-disorders/biology-of-the-lungsand-airways/effects-of-aging-on-therespiratory-system.

LoMauro, A., \& Aliverti, A. (2018). Sex differences in respiratory function. Breathe, 14(2), 131-140.

Mataloni, F., Badaloni, C., Golini, M. N., Bolignano, A., Bucci, S., Sozzi, R., Forastiere, F., Davoli, M., \& Ancona, C. (2016). Morbidity and mortality of people who live close to municipal waste landfills: A multisite cohort study. International Journal of Epidemiology, 45(3), 806-815.

Norsa'adah, B., Salinah, O., Naing, N. N., \& Sarimah, A. (2020). Community health survey of residents living near a solid waste open dumpsite in Sabak, Kelantan, Malaysia. International Journal of Environmental Research and Public Health, 17(1), 311. https://doi.org/10.3390/ ijerph17010311
Okeke, C. U., \& Armour, A. (2000). Post-landfill siting perceptions of nearby residents: A case study of Halton landfill. Applied Geography, 20, 137-154.

Oketola, A. A., \& Akpotu S. O. (2015). Assessment of solid waste and dumpsite leachate and topsoil. Chemistry and Ecology, 31(2), 134-146, DOI: 10.1080/02757540.2014.907280.

Parkinson, C. M., Hammond, D., Fong, G. T., Borland, R., Omar, M., Sirirassamee, B., Awang, R., Driezen, P., \& Thompson, M. (2009). Smoking beliefs and behavior among youth in Malaysia and Thailand. $\mathrm{Am}$ $J$ Health Behav, 33(4), 366-375.

Periathamby, A., Hamid, F. S., \& Khidzir, K. (2009). Evolution of solid waste management in Malaysia: Impacts and implications of the solid waste bill, 2007. Journal of Material Cycles and Waste Management, 11, 96ロ103.

Petry, N. M. (2002). A comparison of young, middle-aged, and older adult treatmentseeking pathological gamblers. The Gerontologist, 42(1), 92-99.

PTJB (2018). (February, 23, 2020). Daerah Telong. https://ptjb.kelantan.gov.my/index. php/en/home/daerah-telong

Rawat, M., \& Ramanathan, A. (2011). Assessment of methane flux from Municipal Solid Waste (MSW) landfill areas of Delhi, India. Journal of Environmental Protection, 2(04), 399-407.

Rusaik, F. (2016). An assessment on health hazards of open dump of solid waste in the Colombo Municipal Council area. 10.13140/RG.2.2.26335.66726. Papers are accepted for the 15th volume of the Sri Lanka Journal of Population Studies (SLJPS) on research conducted on demography or population subjects.

Sharma, S., Hashmi, M. F., Alhajjaj, M. S., \& Cough. (2019, Sep 13). In: StatPearls [Internet]. Treasure Island (FL): StatPearls Publishing; 2019 Jan-. Retrieved from: 
https://www.ncbi.nlm.nih.gov/books/ NBK493221/.

Sheikh, J. (2018). (2019, May 5). Allergic Rhinitis: Practice essentials, background, pathophysiology. https://emedicine. medscape.com/article/134825-overview.

Shusterman, D. (2011). The effects of air pollutants and irritants on the upper airway. Proceedings of the American Thoracic Society, 8(1), 101-105.

Singh, N., \& Singh, V. (2013). Combating cough - Etiopathogenesis. The Journal of the Association of Physicians of India, 61(5 Suppl), 6-7.

Teksoz, G. T. (2011). Managing Air Pollution: How Does Education Help?, The Impact of Air Pollution on Health, Economy, Environment and Agricultural Sources, Mohamed K. Khallaf, IntechOpen, DOI: 10.5772/16679. Retrieved from: https:// www.intechopen.com/books/the-impactof-air-pollution-on-health-economyenvironment-and-agricultural-sources/ managing-air-pollution-how-doeseducation-help-.
USEPA. (2014). Priority pollutant list, Washington.

Voll-Aanerud, M., Eagan, T. M. L., WentzelLarsen, T., Gulsvik, A., \& Bakku, P. S. (2008) Respiratory symptoms, COPD severity, and health related quality of life in a general population sample. Respiratory Medicine, 102(3), 399-406.

Vrijheid, M., Dolk, H., Armstrong, B., Boschi, G., Busby, A., Jorgensen, T., \& Pointer, P. (2002). Hazard potential ranking of hazardous waste landfill sites and risk of congenital anomalies. Occupational and Environmental Medicine, 59(11), 768-776.

World Health Organization (2019) (2019, March 6). Ambient Air Pollution: Health impacts. http://www.who.int/airpollution/ambient/ health-impacts/en/.

Zimmerman, E., \& Woolf, S. H. (2014). Understanding the relationship between education and health. Discuss. Pap. Roundtable Popul. Health, Inst. Med. Washington, DC: Natl. Acad.Sci.http:// www.iom.edu/Global/Perspectives/2014/ UnderstandingTheRelationship.aspx. 